Research Article

\title{
Kegel's Exercise could Reduce the Incidence of Postpartum Urinary Stress Incontinence
}

\section{Senam Kegel dapat Mengurangi Kejadian Stres Inkontinensia Urin Postpartum}

\author{
Nusratuddin Abdullah, Eddy Arsyad \\ Department of Obstetrics and Gynecology \\ Faculty of Medicine University of Hasanuddin/ \\ Dr. Wahidin Sudiro Husodo Hospital \\ Makassar
}

\begin{abstract}
Objective: To investigate the cause of postpartum urinary incontinence in primigravida women and to determine the relationship between stress urinary incontinence and kegel's exercise.

Method: This was an observational study with cross sectional method, performed in institutional hospitals in Makassar. Thirty primigravida women who performed kegel's exercise were compared with 30 primigravida women who did not perform kegel's exercise. Data were analyzed with independent-t statistical analysis.

Result: Urinary incontinence were significantly lower in primigravida women who performed kegel's exercise $(\mathrm{P}=0.000)$.

Conclusion: Kegel's exercise may reduce the incidence of postpartum stress urinary incontinence.

[Indones J Obstet Gynecol 2014; 2: 96-98]
\end{abstract}

Keywords: kegel's exercise, primigravida, urinary Incontinence.

\section{Abstrak}

Tujuan: Mengetahui penyebab stres inkontinensia urin pada wanita primigravida postpartum dan menentukan hubungan antara stres inkontinensia urin dan senam kegel.

Metode: Penelitian observasi dengan desain potong lintang di rumah sakit pendidikan di Makassar. Tiga puluh ibu primigravida dengan senam kegel dibandingkan dengan 30 ibu primigravida tanpa senam kegel sebagai kontrol. Data kemudian dianalisis dengan analisa statistik $t$ independen.

Hasil: Kejadian stres inkontinensia urin lebih rendah secara bermakna pada kelompok senam kegel dibandingkan dengan kelompok kontrol $(P=0,000)$.

Kesimpulan: Senam kegel dapat mengurangi kejadian stres inkontinensia urin postpartum.

[Maj Obstet Ginekol Indones 2014; 2: 96-98]

Kata kunci: primigravida, senam kegel, stres inkontinensia urin.

Correspondence: Eddy Arsyad. Komp Hartoko Indah blok II G/19, Makassar. Telp.: 081354657858 Email: edarsyad@gmail.com

\section{INTRODUCTION}

Pelvic floor dysfunction may cause urinary incontinence, fecal incontinence, pelvic organ prolapse and sexual dysfunction. These symptoms may alter the patient's quality of life. Most of pelvic floor dysfunction were related to pelvic floor damage during labor especially at the first labor (primigra-vida). ${ }^{1}$

Pregnancy and labor may alter the function of pelvic floor muscles due to muscles damage during labor process. About 50\% women experienced vaginal delivery will have genitourinary organ prolapse and $40 \%$ of them will have urinary incontinence.

Stress urinary incontinence is one of the most prevalent type of urinary incontinence occurred in women. One of three women will suffer from urinary incontinence during her life and 65\% clarified that it happened after pregnancy and labor. ${ }^{2}$

Pacific Coast Obstetrical and Gynecological Society, on their annual report in 2001, estimated that until the next 30 years, about $45 \%$ women will need medical procedure due to pelvic floor dysfunction. ${ }^{3}$

The kegel's exercise was aimed to train and strengthen the pelvic floor muscles. ${ }^{4}$ By positively thinking pregnant women may plan to participate in safe and effective exercise program during pregnancy. Actually this kegel's exercise may leads women to healthier and happier pregnancy.

According to Purnomo in 2003, kegel's exercise is the most popular non operative therapy for urinary incontinence. This exercise may strengthen the pelvic muscles, urethral and periurethral muscles and thus improve their tones. ${ }^{5}$ 
Performing kegel's exercise during pregnancy and after delivery may help the pelvic muscles to regain their normal function. Furthermore, doing this exercise regularly may prevent uterine prolapse and urinary incontinence. ${ }^{5}$

According to a previous study, the success rate of pelvic muscles training in preventing urinary incontinence was $56-75 \%{ }^{6}$

Twenty percent of postpartum women who had urinary incontinence and performed pelvic floor exercises reported symptoms improvement compared to non exercise women. Thus, the more time this exercise program performed, the more apparent the effect. ${ }^{7}$

\section{METHODS}

This study was an observational study using cross sectional approach. The research was performed in Dr. Wahidin Sudiro Husodo Hospital, Siti Fatimah Hospital, Bhayangkara Hospital, Haji Hospital, Syech Yusuf Gowa Hospital and Salewangang Maros Hospital from September 2012 to December 2012.

Samples were obtained from all primigravida women with gestational age of more than 32 weeks who came to the hospital for routine antenatal screening.

The sampling methods performed were consecutive sampling. From the sample calculation, the minimum number of 60 samples is required, from which 30 samples were grouped into kegel's exercise group and the rest were grouped into non kegel's exercise or control group.

The data were obtained using measurement tool such as questionnaires. Data were analyzed using Statistical Program for Social Sciences (SPSS) for windows version 16 . Statistical test using t test and correlation test.

\section{RESULTS}

Samples characteristics showed that there were 30 women who performed kegel's exercise and 30 women who did not perform kegel's exercise. Age, birth weight, occupation, and labor difficulty score between two groups were not significantly different ( $\mathrm{p}>0.05)$. But most subjects in kegel's exercise group $(64.1 \%)$ were highly educated (Senior High school or higher).
We found that 23 women had urinary incontinence postpartum, in which 19 women (63.3\%) belongs to non kegel's exercise group and only 4 women $(13.3 \%)$ belongs to kegel's exercise group.

$\mathrm{X}^{2}$ statistical analysis was applied and we found that urinary incontinence was significantly lower ini kegel's exercise group $(\mathrm{p}<0.05)$.

We also found that women with higher education (Senior High school or higher) had less urinary incontinence compared to lower educational group (elementary or lower secondary school) as seen in $\mathrm{X}^{2}$ statistical analysis with $\mathrm{p}<0.05$.

When we combined the educational status and kegel's exercise contribution in preventing the urinary incontinence, we found that the kegel's exercise was not significant in lowering the urinary incontinence in lower educational group, but it had positive contribution in lowering the urinary incontinence in higher educational group $(p<0.05)$.

\section{DISCUSSION}

This study had observed two groups of primigravida women, one with kegel's exercise and another one without kegel's exercise. The observation was continued until one week postpartum. Both groups were compared to investigate the incidents of stress urinary incontinence after delivery. Total samples were 60 women and they were divided into two groups, 30 women as kegel's exercise group and another 30 as non kegel's exercise group.

Characteristic such as age, birth weight, occupational status, labor difficulty were not significantly different in both groups ( $p>0.05$ ).

Data showed us that primigravida women who gave birth a child with birth weight $>3000$ gram tends to have urinary incontinence. This finding is appropriate with Cammu's study in 2000. He found that women who gave birth a child with birth weight $>4000$ gram tend to have urinary incontinence after delivery (postpartum) because the labor process with bigger baby tend to damage the pelvic floor's nerves.

Damage of structure and function of pelvic floor muscles will cause the urinary incontinence. This damage, mostly, have a close relationship with pelvic floor damage during vaginal delivery process. $^{8}$ 
Type of urinary incontinence that mostly happen in postpartum women is stress urinary incontinence. This stress urinary incontinence occurred due to inability of urethral sphincter to maintain the intraurethral pressure during the filling phase of bladder. In this phase the bladder's pressure increases. The pressure may also increase if the intra abdominal pressure is increasing, whereas this pressure may be triggered by coughing, sneezing, laughing, walking, standing, or lifting heavy items. ${ }^{2}$

Incident of urinary incontinence in kegel's exercise group is significantly lower in control/non kegel's exercise group ( $13.2 \%$ vs $63.3 \%$; $\mathrm{p}=0.000$ ). This study showed us that kegel's exercise during pregnancy may lower the incident of urinary incontinence in primigravida postpartum women.

Bo's opinion in 2004 was appropriate with our findings. He said that pelvic floor exercise program (kegel's exercise) had a positive influence for individual with stress urinary incontinence.

We found that most subjects with urinary incontinence had graduated lower secondary school $(66.7 \%)$ and most subjects with no urinary incontinence had graduated high school or higher (74.4\%). Statistical analysis with ANOVA showed that the difference is statistically significant $(\mathrm{p}<0.05)$.

When we combined the contribution of educational status and kegel's exercise in preventing urinary incontinence, we found that the kegel's exercise was not significant in lowering the urinary incontinence in lower educational group, but it had positive contribution in lowering the urinary incontinence in higher educational group $(\mathrm{p}<0.05)$.
The same opinion was implied by Ulya and Noor (2008) that educational status plays an important role in kegel's exercise practice $(\mathrm{p}=0.000$ and $\mathrm{r}=$ $0.715)$.

\section{CONCLUSIONS}

Kegel's exercise had positive influence in reducing the incident of urinary incontinence in postpartum primigravida women. Kegel's exercise had no positive influence in reducing incident of urinary incontinence in lower educational group (elementary or lower secondary school) but had positive influence in higher educational group (high school or higher), thus kegel's exercise may be adapted as a routine antenatal program to prevent postpartum urinary incontinence

\section{REFERENCES}

1. Junizaf. Buku ajar uroginekologi indonesia. FKUI 2011.

2. Wyman J. Treatment of urinary incontinence in men and older women. AJN 2003; 103(3): 26-35.

3. Nygaard I. Stress urinary incontinence. Obstet Gynecol 2004; 104: 607-20.

4. Holroyd-Leduc, Straus S. Mnagement of urinary incontinence in women: scientific review. JAMA 2004; 291(8): 986-95.

5. Bobak. The muscles of the pelvic floor. Clin Obstet Gynecol 2004; 36: 910-24.

6. Freeman, editor. Epidemiology of incontinence. Baltimore: Williams \& Wilkins; 2004.

7. Smith C, Miller J, Mims B, DeLancey J, Ashton-Miller J, Antanakos C. Effect of pelvic muscle exercise on transient incontinence during pregnancy and after birth. Obstet Gynecol 2009; 91: 406-12.

8. Herschorn S. Female pelvic floor anatomy: the pelvic floor, supporting structures and pelvic organs. Rev Urol 2004; 6(5): 2-10. 